\title{
A RESERVA DE CARGOS E EMPREGOS PÚBLICOS PARA AS PESSOAS COM DEFICIÊNCIA COMO ESTRATÉGIA CONSTITUCIONAL RUMO À IGUALDADE CONCRETA
}

\author{
THE RESERVATION OF PUBLIC JOBS FOR PERSONS WITH DISABILITIES AS A \\ CONSTITUTIONAL STRATEGY TOWARDS SUBSTANTIVE EQUALITY
}

\section{LA RESERVA DE CARGOS Y EMPLEOS PÚBLICOS PARA PERSONAS CON DISCAPACIDAD COMO ESTRATEGIA CONSTITUCIONAL HACIA LA IGUALDAD EFECTIVA}

\author{
EDILENE LÔBO \\ https://orcid.org/0000-0003-4043-0286 / http://lattes.cnpq.br/6348105561410653 / edilenelobo@yahoo.com.br \\ Universidade de Itaúna. \\ Itaúna, MG, Brasil.
}

\author{
BRUNO MARTINS TEIXEIRA \\ https://orcid.org/0000-0001-9319-2758 / http://lattes.cnpq.br/6684657345649128 / brunomarteixeira@gmail.com \\ Universidade de Itaúna. \\ Itaúna, MG, Brasil.
}

\begin{abstract}
RESUMO
0 presente artigo indaga acerca da concretização do direito constitucional que trata da reserva de cargos e empregos públicos para as pessoas com deficiência, partindo da importância histórica das ações afirmativas nesse campo, perquirindo a valorização da igualdade na práxis. Também é objetivo verificar o acesso dessas pessoas ao mercado de trabalho, questionando os entraves que o sistema econômico apresenta à referida inclusão. Por fim, examina como vem sendo efetivado o direito fundamental em tela. Norteado pelo referencial constitucional, cujo objetivo é erradicar a marginalização e a discriminação, utilizou-se o método dedutivo, com aplicação da técnica de pesquisa bibliográfica. Conclui-se, arrematando, que para além do aprimoramento da legislação ordinária e da incisiva atuação na capacitação dos destinatários dessa importante regra constitucional, há que se adotar novas práticas na Administração Pública, voltadas à valorização das habilidades de tais pessoas, sob fiscalização incessante dos órgãos competentes.
\end{abstract}

Palavras-chave: Ação Afirmativa; Estratégia constitucional; Igualdade concreta; Pessoas com deficiência; Reserva de vagas no serviço público.

\begin{abstract}
The present article inquiries about the implementation of the Constitutional Law that deals with the reservation of employment and public office for disabled, starting from the historical importance of affirmative actions in this area, investigating the valuation of equality in praxis. It is also a goal to verify the access of these people to the labor market, questioning the obstacles that the economic system presents to the inclusion mentioned. Lastly, it examines how the fundamental right under discussion has been realized. Guided by the constitutional referential, whose purpose is to eradicate marginalization and discrimination, used the deductive method with the application of the bibliographic research technique. Finally, it's concluded that, in addition to the improvement of the ordinary legislation and the incisive action in the training of the recipients of this important constitutional rule, it is necessary to adopt new practices in Public Administration, on valuing the skills of such people.
\end{abstract}

Keywords: Affirmative Action; Constitutional strategy; Substantive Equality; Disabled people; Reservation of vacancies in the public service. 


\section{RESUMEN}

Este artículo discute la concreción del derecho constitucional que se encarga de puestos y cargos públicos reservados a discapacitados, a partir de la importancia histórica de acciones afirmativas en ese campo, averiguando la valoración de la igualdad en la praxis. También busca saber sobre el acceso de esas personas al mercado laboral, poniendo en tela de juicio las barreras que el sistema económico impone a esa inclusión. Por fin, examina, cómo se efectiva, el derecho fundamental en punto de mira. Orientado por referencia constitucional, que objetiva erradicar la marginación y el prejuicio, se utilizó el método deductivo aplicándose la técnica de investigación bibliográfica. Se concluye, a final, que más allá de la mejoría de la legislación ordinaria y de la incisiva actuación en la capacitación de los destinatarios de esa importante regla constitucional, hay que adoptar nuevas prácticas en la Administración Pública, destinadas a valorar las habilidades de dichas personas, bajo continua vigilancia de los órganos competentes.

Palabras clave: Acción Afirmativa; Estrategia constitucional; Igualdad efectiva; Personas con discapacidad; Reserva de vacantes en el sector público.

\section{SUMÁRIO}

INTRODUÇ̃̃O; 1 IGUALDADE JURÍDICA, AÇÃO AFIRMATIVA E PESSOAS COM DEFICIÊNCIA; 1.1 Igualdade substancial e democracia; 1.2 A tensão entre igualdade substancial e os reclames do mercado de trabalho; 1.3 Evolução histórica; 2 ACESSO DA PESSOA COM DEFICIÊNCIA AO MERCADO DE TRABALHO; 2.1 Avanços na inclusão de pessoas com deficiência na iniciativa privada; 3 CONCRETIZAÇÃO CONSTITUCIONAL DO ACESSO A CARGO OU EMPREGO PÚBLICO; 3.1 A inclusão de pessoas com deficiência na esfera pública; 3.2 As normativas do CNJ e do CNMP para inclusão das pessoas com deficiência; 3.30 dever de fiscalização; CONCLUSÃO; REFERÊNCIAS.

\section{INTRODUÇÃO}

Segundo o último censo demográfico do IBGE, cerca de 45,6 milhões de pessoas - 23,9\% da população brasileira - declararam ter pelo menos uma deficiência. ${ }^{1}$ Desse total, apenas 418,5 mil - menos de $1 \%$ - estão empregadas. ${ }^{2}$

Esse cenário, contudo, já foi bem pior. Durante a Revolução Industrial (séculos XVIIIXIX), havia pouquíssimo espaço para essa minoria, em especial no tocante às oportunidades de trabalho. Imperava, de forma extrema, o preconceito de que a admissão dessas pessoas poderia significar prejuízo à produtividade das empresas e entidades públicas que as contratassem³.

\footnotetext{
1 INSTITUTO BRASILEIRO DE GEOGRAFIA E ESTATÍ́STICA - IBGE. Rio de Janeiro: RJ. Boletim estatístico censo 2010. Disponível em: https://biblioteca.ibge.gov.br/visualizacao/periodicos/94/ cd_2010_religiao_deficiencia.pdf. Acesso em: 24 mar. 2018, p. 73.

${ }^{2}$ MINISTÉRIO DO TRABALHO E EMPREGO. Relatório Anual de Informações Sociais - RAIS - 2016. In: Dados Nacionais 2016, 3. Análise dos principais resultados. Brasília - DF. Disponível em: http://pdet.mte.gov.br/rais?view=defaul. Acesso em: 01 maio. 2018.

${ }^{3}$ GUGEL, Maria Aparecida. Pessoas com deficiência e o direito ao concurso público. - Reserva de cargos e empregos públicos - Administração Pública direta e indireta. 3. ed. Goiânia: Editora da UGC, 2016, p. 08.
} 
ISSN 1981-3694

(DOI): $10.5902 / 1981369432608$

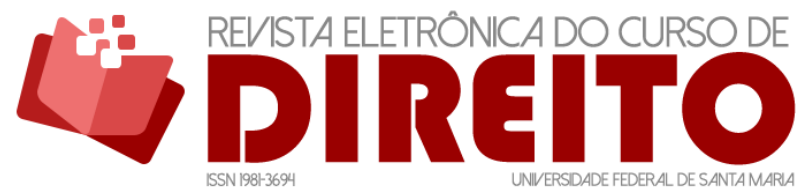

A RESERVA DE CARGOS E EMPREGOS PÚBLICOS PARA AS PESSOAS COM DEFICIÊNCIA COMO ESTRATÉGIA CONSTITUCIONAL RUMO À

IGUALDADE CONCRETA

EDILENE LÔBO

BRUNO MARTINS TEIXEIRA

No início do século passado, com o surgimento do movimento denominado Constitucionalismo Social a partir do término da Primeira Guerra Mundial, ampliaram-se consideravelmente os mecanismos de proteção dos direitos fundamentais, máxime o direito ao trabalho digno ${ }^{4}$.

Desde então, assistiu-se à formação de um arcabouço normativo cada vez mais robusto, voltado para a promoção da igualdade por meio do respeito à diversidade e à dignidade em todas as esferas de direitos.

A implementação das ações afirmativas a partir da segunda metade do século XX, em resposta às reivindicações que vinham sendo apresentadas de forma cada vez mais contundente pelos diversos grupos vulneráveis excluídos, serviu de base para a construção de uma ordem jurídico-constitucional efetivamente comprometida com a proteção das minorias, e com a promoção de uma inclusão mais concreta.

Nesse contexto, o amparo jurídico do trabalhador com deficiência passou a fazer parte do ordenamento internacional e das normas internas de vários países, principalmente com a previsão de medidas voltadas para a efetiva inclusão desse público no mercado de trabalho. Como consequência, a ampliação do direito desses cidadãos aos cargos e empregos públicos passou a receber maior amparo constitucional. Na órbita interna, a legitimação dessa garantia encontra-se no artigo 37, VIII, da Constituição, cuja previsão resguarda percentual de cargos e empregos públicos para servidores com deficiência.

Ocorre que a legislação infraconstitucional que se editou no intuito de dar concretude ao referido preceito não se conforma perfeitamente aos objetivos claramente enunciados pelo dispositivo constitucional em tela.

Tornou-se lugar comum, em todas as esferas públicas, tão somente estabelecer a reserva de percentual das vagas ofertadas nos concursos públicos. Diversamente, como se verá, a efetivação do direito previsto pelo legislador constituinte implica resguardar para essas pessoas, provendo-os, uma porcentagem mínima de cargos dentro do quadro funcional de cada entidade.

Passadas três décadas da vigência do dispositivo em comento, mantém-se um grave descompasso entre a quantidade de pessoas com alguma deficiência na sociedade e a parcela de servidores com deficiência ocupando cargos e empregos públicos. Tal fenômeno merece amplo debate e sério enfrentamento.

\footnotetext{
${ }^{4}$ MARTINS, Sérgio Pinto. Direito do Trabalho. 19. ed. São Paulo: Editora Atlas, 2001, p. 41.
} 
ISSN 1981-3694

(DOI): $10.5902 / 1981369432608$

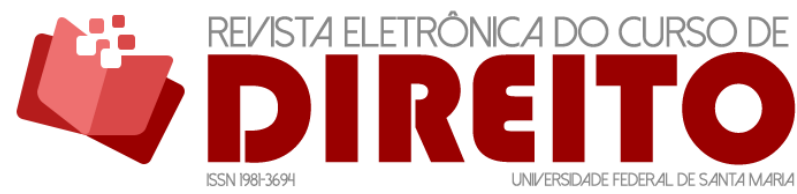

A RESERVA DE CARGOS E EMPREGOS PÚBLICOS PARA AS PESSOAS COM DEFICIÊNCIA COMO ESTRATÉGIA CONSTITUCIONAL RUMO À

IGUALDADE CONCRETA

EDILENE LÔBO

BRUNO MARTINS TEIXEIRA

Eis a proposta deste trabalho, que se desenvolve, primeiramente, abordando a igualdade jurídica e as correspondentes ações afirmativas para fazê-la efetiva, buscando a substancialidade, demonstrando sua importância em plena era da luta contra a discriminação e a erradicação da marginalidade no mundo global.

Nessa quadra, aferindo medidas do plano interno, na sequência, se destacam os obstáculos ao acesso da pessoa com deficiência ao mercado de trabalho, realçando os documentos internacionais que impactaram de modo significativo a legislação e a jurisprudência nacionais dirigidas à esfera privada - muito melhores que aquelas dedicadas aos cargos e empregos públicos.

$\mathrm{Na}$ parte em que aborda o acesso das pessoas com deficiência às esferas públicas, o trabalho registra que mesmo com o patamar mínimo previsto nas leis, os concursos apenas reservam vagas, mas a nomeação é quimera, havendo, quando muito, a alocação dos classificados em cadastro de reserva, realçando o déficit a ser combatido.

Buscando examinar a realidade, pinçou-se concursos das duas mais importantes carreiras jurídicas, de Promotor de Justiça e de Juiz, nos dois maiores Estados da Federação brasileira, Minas Gerais e São Paulo, para estampá-la sem sofismas e permitir alguma ideia sobre o que sucede em geral. Ao fazê-lo, verificou-se que mesmo com a obrigação de fiscalizar o cumprimento da regra constitucional, nem o Ministério Público tem garantido nomeação de pessoas com deficiência para prover quadro próprio, fato que se repete na magistratura, cujo órgão central de controle, o Conselho Nacional de Justiça, mediante resolução recente, apenas copia o texto constitucional.

Sob os influxos do referente teórico constitucional de erradicação da discriminação, do preconceito e da marginalidade (art. $3^{\circ}$, III e IV, da Constituição), utilizando o método dedutivo, com aplicação da técnica de pesquisa bibliográfica, conclui-se que para além do aperfeiçoamento da legislação ordinária e da incisiva atuação na capacitação dos destinatários do direito fundamental em espeque, há que se buscar novas práticas na Administração Pública, em especial indexando o percentual legal ao provimento dos cargos e empregos criados, doravante, valorizando as habilidades de tais pessoas, sob fiscalização incessante em todos os órgãos do Estado, incluído o Poder Judiciário e o Ministério Público, ambos com imensa visibilidade em tempos de judicialização da vida ${ }^{5}$.

${ }^{5}$ BARROSO, Luís Roberto. A judicialização da vida e o papel do Supremo Tribunal Federal. Belo Horizonte: Forum, 2018. 
ISSN 1981-3694

(DOI): $10.5902 / 1981369432608$

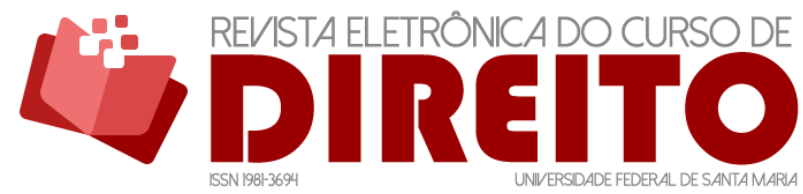

\section{IGUALDADE JURÍDICA, AÇÃO AFIRMATIVA E PESSOAS COM DEFICIÊNCIA}

A partir da segunda metade do século XX, principalmente em decorrência das graves marcas deixadas pelas duas Guerras Mundiais, a comunidade internacional deu início a um importante movimento de ampliação da normatividade e de busca de maior efetivação do direito à igualdade enquanto direito fundamental.

O surgimento da Organização das Nações Unidas - ONU, criada oficialmente em 1945, foi um dos marcos mais relevantes para que esse intento fosse levado adiante. A Carta das Nações Unidas, ratificada no Brasil por meio do Decreto $n^{\circ}$ 19.841, de 22 de outubro de 1945, apresenta como principal motivo de sua criação propiciar meios para que as futuras gerações não sofram os horrores de uma guerra, devendo-se proteger os direitos fundamentais, em especial a dignidade e a igualdade de direito dos homens e das mulheres.

\subsection{Igualdade substancial e democracia}

O princípio da igualdade constitui hoje um dos pilares mais importantes da Democracia. Em sua definição clássica, consiste em "aquinhoar desigualmente aos desiguais, na medida em que se desigualam." Em outras palavras, significa dizer que a aplicação desse princípio terá lugar sempre que for necessário equilibrar uma situação injusta de desigualdade, legitimando-se o rompimento da desigualdade formal para propiciar uma igualdade material, concreta.

Com a Constituição de 1988, a sociedade brasileira afiança claro comprometimento social no tocante à realização desse princípio. Vemos que o preâmbulo da Constituição, ao cuidar da garantia do exercício da igualdade como um dos valores supremos de uma sociedade fraterna, pluralista e sem preconceitos, firma o comprometimento não só da atuação estatal, como de todos os atores sociais, inclusive dos cidadãos. Sobre esse ponto, é interessante o voto da ministra Carmem Lúcia na relatoria da Ação Direta de Inconstitucionalidade n. ${ }^{\circ}$ 2.649:

[...] Vale, assim, uma palavra, ainda que brevíssima, ao Preâmbulo da Constituição, no qual se contém a explicitação dos valores que dominam a obra constitucional de 1988 [...]. Não apenas o Estado haverá de ser convocado para formular as políticas públicas que podem conduzir ao bem-estar, à igualdade e à justiça, mas a sociedade haverá de se organizar segundo aqueles valores, a fim

6 BARBOSA, Rui. Oração aos Moços. 5. Ed. Rio de Janeiro: Edições Casa de Rui Barbosa, 1999. p.26. 
ISSN 1981-3694

(DOI): $10.5902 / 1981369432608$

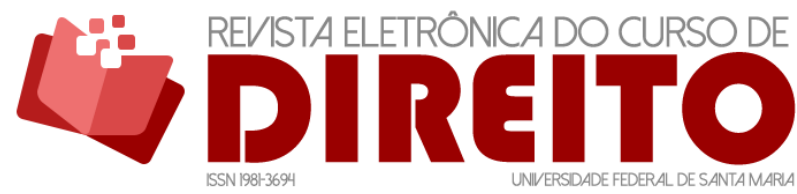

A RESERVA DE CARGOS E EMPREGOS PÚBLICOS PARA AS PESSOAS COM DEFICIÊNCIA COMO ESTRATÉGIA CONSTITUCIONAL RUMO À

IGUALDADE CONCRETA

EDILENE LÔBO BRUNO MARTINS TEIXEIRA

de que se firme como uma comunidade fraterna, pluralista e sem preconceitos $[\ldots]^{7}$

Com efeito, o artigo $5^{\circ}$, núcleo da proteção constitucional dos direitos fundamentais, finca os alicerces do Estado Democrático de Direito ao assentar que todos são iguais perante a lei, sem distinção de qualquer natureza.

\subsection{A tensão entre igualdade substancial e os reclames do mercado de trabalho}

Diante da crescente desigualdade econômica que cada vez mais assola a população, foi necessário que o ideal de concretização da igualdade material abarcasse, sobretudo, os direitos sociais, principalmente o direito ao trabalho. Esse fenômeno ganhou ainda mais valor no final do século XX e início deste século, mormente em função de o capitalismo mundial ter situado a individualidade e a competitividade como valores prioritários, muitas vezes sobrepondo-os ao princípio da solidariedade social e à busca por um tratamento igualitário.

Em consequência, formou-se nos últimos anos uma grande tensão entre o advento de uma lógica essencialmente mercantilista e o esforço social na busca da efetivação dos direitos fundamentais consagrados no texto constitucional.

Nesse sentido, José Afonso da Silva diz que:

[...] a igualdade constitui o signo fundamental da democracia. Não admite os privilégios e distinções que um regime simplesmente liberal consagra. Por isso é que a burguesia, cônscia de seu privilégio de classe, jamais postulou um regime de igualdade tanto quanto reivindicara o de liberdade. É que um regime de igualdade contraria seus interesses e dá à liberdade sentido material que não se harmoniza com o domínio de classe em que assenta a democracia liberal burguesa. ${ }^{8}$

Jorge Miranda ensina que o sentido primário do princípio da igualdade é negativo e implica até em responsabilidade de reparar danos ocasionados com a discriminação:

Não se trata, de resto, apenas de proibir discriminações. Trata-se também de proteger as pessoas contra discriminações [...]; de as proteger, se necessário, por via penal e, eventualmente, com direito a reparação à face dos princípios gerais de responsabilidade. ${ }^{9}$

\footnotetext{
7 BRASIL. Supremo Tribunal Federal. Ação Direta de Inconstitucionalidade $n^{\circ}$ 2.649. Relatora: Carmem Lúcia. DF. Publicação DJE em 17/10/2008. Disponível em: http://www.stf.jus.br/portal/constituicao/artigobd.asp?item=\%202. Acesso em: $24 \mathrm{fev} 2018$.

${ }^{8}$ SILVA, José Afonso da. Curso de direito constitucional positivo. 40. ed. São Paulo: Malheiros, 2017, p. 212.

${ }^{9}$ MIRANDA, Jorge. Direitos Fundamentais. Coimbra: Edições Almedina S.A., 2017, p. 302.
} 
ISSN 1981-3694

(DOI): $10.5902 / 1981369432608$

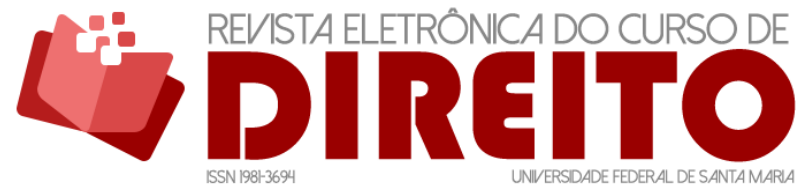

A RESERVA DE CARGOS E EMPREGOS PÚBLICOS PARA AS PESSOAS COM DEFICIÊNCIA COMO ESTRATÉGIA CONSTITUCIONAL RUMO À

IGUALDADE CONCRETA

EDILENE LÔBO BRUNO MARTINS TEIXEIRA

A Constituição vigente, imbuída da missão de dar concretude ao pacto da construção de uma sociedade mais justa, na forma do inciso IV do artigo $3^{\circ}$, fixou sólidos fundamentos para as políticas relativas à promoção da igualdade. Por meio do citado dispositivo, convoca-se todo cidadão à promoção do bem comum, proibindo-se quaisquer tipos de preconceitos e ações discriminatórias. Em adesão a esses fundamentos, no tocante à dignidade nas relações de trabalho, a Constituição traçou importante objetivo no art. 170 ao dispor que "A ordem econômica, fundada na valorização do trabalho humano e na livre iniciativa, tem por fim assegurar a todos existência digna, conforme os ditames da justiça social [...]."10

Frisa-se que a escolha do vocábulo "promover" (art. $3^{\circ}$, IV), para além de traçar um dos objetivos fundamentais constituídos pelo povo brasileiro, representa a adoção de um posicionamento popular proativo institucionalizado, com a materialização de ações afirmativas tendentes a corrigir efetivamente os rumos das desigualdades ainda presentes.

Conforme lição de Carmen Lúcia Antunes Rocha:

A expressão ação afirmativa, utilizada pela primeira vez na ordem executiva federal norte-americana do mesmo ano de 1965, passou a significar desde então, a exigência de favorecimento de algumas minorias socialmente inferiorizadas, vale dizer, juridicamente desigualadas, por preconceitos arraigados culturalmente e que precisavam ser superados para que se atingisse a eficácia da igualdade preconizada e assegurada constitucionalmente na principiologia dos direitos fundamentais. ${ }^{11}$

Com maior detalhamento, Maria Aparecida Gugel anota que:

A ação afirmativa, com fundamento no princípio do direito à igualdade, exige do Estado e da sociedade a construção de um ordenamento jurídico que mostre os fins sociais, a proteção dos valores da justiça social e do bem comum, de forma a implementar os comandos programáticos constitucionais do artigo $3^{\circ}$, inciso III da Constituição da República, visando a erradicar e reduzir as desigualdades sociais; promover o bem de todos, sem preconceitos e quaisquer formas de discriminação (artigo $3^{\circ}$, inciso IV da Constituição da República) [...] reduzir as desigualdades regionais e sociais (artigo 170, inciso VII da Constituição da República). ${ }^{12}$

\footnotetext{
${ }^{10}$ BRASIL. Brasília. Presidência da República. Constituição da República Federativa do Brasil, de 05 de outubro de 1988. Disponível em: http://www.planalto.gov.br/ccivil_03/Constituicao/Constituicao.htm. Acesso em: 22 mar. 2018.

11 ROCHA, Carmen Lúcia Antunes. Ação Afirmativa: O Conteúdo Democrático do Princípio da Igualdade Jurídica. Revista da Informação Legislativa, v. 33, n 131, p. 285, jul./set. de 1996. Disponível em: http://www2.senado.gov.br/bdsf/item/id/176462. Acesso em: 05 fev. 2017.

12 GUGEL, Maria Aparecida. Pessoas com deficiência e o direito ao concurso público. - Reserva de cargos e empregos públicos - Administração Pública direta e indireta. 3. ed. Goiânia: Editora da UGC, 2016, p. 91.
} 
ISSN 1981-3694

(DOI): $10.5902 / 1981369432608$

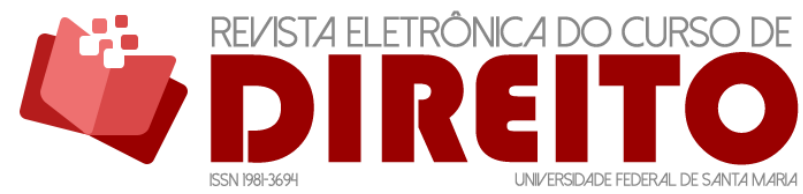

A RESERVA DE CARGOS E EMPREGOS PÚBLICOS PARA AS PESSOAS COM DEFICIÊNCIA COMO ESTRATÉGIA CONSTITUCIONAL RUMO À

IGUALDADE CONCRETA

EDILENE LÔBO BRUNO MARTINS TEIXEIRA

Essa autora aposta na ideia da ação afirmativa como "conjunto de medidas legais e de políticas públicas que objetivem eliminar as diversas formas e tipos de discriminação que limitam oportunidades de determinados grupos sociais"13.

Dentre os grupos vulneráveis carecedores de um tratamento diferenciado mais efetivo, merecem destaque as pessoas com deficiência, eis que ainda permanecem à margem do usufruto normal de um sem número de aspectos da vida em sociedade.

\subsection{Evolução histórica}

Até o início do século XX esses indivíduos não recebiam justa acolhida no acesso à educação, ao mercado de trabalho, às condições de transporte e às demais prioridades básicas disponíveis à população. Somente após a Segunda-Guerra Mundial é que surge a consciência global de valorização desses cidadãos, muito motivadamente em razão do impactante retorno dos combatentes que serviram nas batalhas e que voltavam com sérias lesões.

No âmbito jurídico internacional, a Declaração Universal dos Direitos Humanos sobrelevou o respeito ao direito à igualdade ao inscrever no seu artigo I que "todas as pessoas nascem livres e iguais em dignidade e direitos." 14

Desde então, a produção de normas internacionais cuidando da proteção e promoção das pessoas com deficiência teve uma evolução crescente. É que o mais das vezes as deficiências, principalmente as físicas, não passam despercebidas, muito menos em um contexto marcado por um modelo econômico em que produtividade e lucro são apresentados como objetivos principais.

Em meio a tais mudanças, a Constituição de 1988 contemplou inúmeros desses direitos de forma expressa em seu texto, conferindo amplo tratamento à proteção e à inclusão da pessoa com deficiência: proibiu expressamente o seu tratamento discriminatório no tocante a salário e critérios de admissão (art. $7^{\circ}, \mathrm{XXXI}$ ); delegou competência comum aos entes federativos no que diz respeito à implementação de mecanismos para sua proteção (art. 23, II); previu competência legislativa concorrente para sua integração (art. 24, XIV); garantiu maior acesso aos cargos públicos (art. 37, VIII) e maior integração à vida comunitária (art. 203, IV); garantiu, ainda,

13 GUGEL, Maria Aparecida. Pessoas com deficiência e o direito ao concurso público. - Reserva de cargos e empregos públicos - Administração Pública direta e indireta. 3. ed. Goiânia: Editora da UGC, 2016, p. 91.

14 ORGANIZAÇÃO DAS NAÇ̃̃ES UNIDAS - ONU. Declaração Universal dos Direitos Humanos. Aprovada pela Resolução n.217, durante a assembleia-Geral da ONU, em Paris, França, em 10/12/1948. Disponível em: https://nacoesunidas.org/wp-content/uploads/2018/10/DUDH.pdf. Acesso em: 22 jan.2018. 
ISSN 1981-3694

(DOI): $10.5902 / 1981369432608$

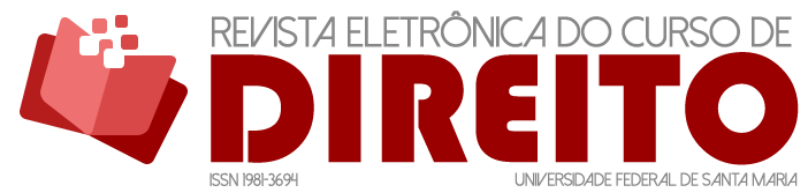

A RESERVA DE CARGOS E EMPREGOS PÚBLICOS PARA AS PESSOAS COM DEFICIÊNCIA COMO ESTRATÉGIA CONSTITUCIONAL RUMO À

IGUALDADE CONCRETA

EDILENE LÔBO BRUNO MARTINS TEIXEIRA

atendimento educacional especializado e criação de programas de prevenção e atendimento especializado (arts. 208, III e $227, \$ 1^{\circ}$, II) e determinou a normatização acerca da acessibilidade física e de transporte público (arts. $227, \$ 2^{\circ}$ e 244 ). Esse "sobrevoo" sobre o texto constitucional permite-nos visualizar como já vinha sendo percebida a importância da questão no final do século passado.

Um importante marco regulatório foi inaugurado com a publicação da Convenção sobre os Direitos das Pessoas com Deficiência, CDPD, aprovada no Brasil por meio do Decreto Legislativo n. 186, de 09/07/2008, e promulgada pelo Decreto n. 6949, de 25/08/2009. É preciso frisar que o citado Decreto detém status de Emenda Constitucional, pois que se enquadra na previsão do art. 5, § $4^{\circ}$ da Constituição de 1988.

No seu artigo $1^{\circ}$, a CDPD exalta o propósito de "promover, proteger e assegurar o exercício pleno e equitativo de todos os direitos humanos, as liberdades fundamentais por todas as pessoas com deficiência e promover o respeito pela sua dignidade inerente". No mesmo artigo $1^{\circ}$ é apresentada a definição de pessoas com deficiência:

Pessoas com deficiência são aquelas que têm impedimentos de longo prazo de natureza física, mental, intelectual ou sensorial, os quais, em interação com diversas barreiras, podem obstruir sua participação plena e efetiva na sociedade em igualdades de condições com as demais pessoas. ${ }^{15}$

As disposições da CDPD vieram coroar os esforços da empreitada instaurada pelo Direito Internacional desde a segunda metade do século XX, constituindo o principal núcleo normativo protetivo das pessoas com deficiência no direito brasileiro, enquanto parte integrante da nossa Constituição. Além disso, é a base normativa principal do Estatuto da Pessoa com Deficiência, materializado na Lei 13.146, de 06 de julho de 2015, cujas regras, além de se pautarem rigorosamente nos mesmos princípios, abordam minúcias importantes da vida social dessas pessoas na atualidade, máxime quanto à educação (arts. 27 a 30) e ao trabalho (arts. 34 a 35). ${ }^{16}$

\section{ACESSO DA PESSOA COM DEFICIÊNCIA AO MERCADO DE TRABALHO}

Um dos maiores desafios que se apresentam na perspectiva da CDPD diz respeito à inclusão das pessoas com deficiência no mercado de trabalho, seja no âmbito privado ou

15 BRASIL. Presidência da República. Decreto 6.949, de 25/08/2009. Disponível em: http://www.planalto.gov.br/ccivil_03/_Ato2007-2010/2009/Decreto/D6949.htm. Acesso em 05 set. 2017. 16 BRASIL..Brasília. Presidência da República. Lei 13.146, de 06/07/2015. Disponível em: http://www.planalto.gov.br/ccivil_03/_ato2015-2018/2015/lei/l13146.htm. Acesso em: 22 mar. 2018. 
ISSN 1981-3694

(DOI): $10.5902 / 1981369432608$

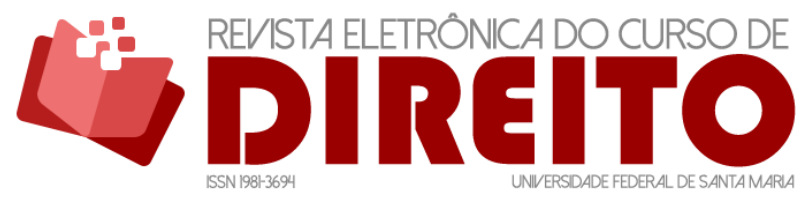

A RESERVA DE CARGOS E EMPREGOS PÚBLICOS PARA AS PESSOAS COM DEFICIÊNCIA COMO ESTRATÉGIA CONSTITUCIONAL RUMO À

IGUALDADE CONCRETA

EDILENE LÔBO BRUNO MARTINS TEIXEIRA

público. Com as mudanças acontecidas durante o período industrial, somadas às novidades trazidas pela era pós-industrial, passou-se a exigir um nível cada vez mais alto de eficiência nos processos de trabalho.

A preocupação com a empregabilidade da pessoa com deficiência surge no bojo da Declaração Universal dos Direitos Humanos, (1948), que previu no seu artigo XXIII, que "toda pessoa tem direito ao trabalho, à livre escolha de emprego, a condições justas e favoráveis de trabalho e à proteção contra o desemprego."

Também se deve fazer menção à Convenção n. 159, da Organização internacional do Trabalho - OIT, de $1983^{17}$, que estabelece sobre a Reabilitação Profissional e Emprego das Pessoas Deficientes. No seu artigo 4, ao tratar dos princípios fundamentais de sua política, reza que:

Artigo 4 - Essa política deverá ter como base o princípio de igualdade de oportunidades entre os trabalhadores deficientes e os trabalhadores em geral. Dever-se-á respeitar a igualdade de oportunidades e de tratamento para as trabalhadoras deficientes. As medidas positivas especiais com a finalidade de atingir a igualdade efetiva de oportunidades e de tratamento entre trabalhadores deficientes e os demais trabalhadores, não devem ser vistas como discriminatórias em relação a estes últimos .Visando os mesmos objetivos, no que atine às oportunidades de trabalho, diz o artigo XXIII, ítem 1, da citada Convenção, que "todo ser humano tem direito ao trabalho, à livre escolha de emprego, a condições justas e favoráveis de trabalho e à proteção contra o desemprego. ${ }^{18}$

A Convenção sobre os Direitos das Pessoas com Deficiência - CDPD (Decreto n. 6949, de 25/08/2009), no seu artigo 27 diz que "Os Estados Partes reconhecem o direito das pessoas com deficiência ao trabalho, em igualdade de oportunidades com as demais pessoas.", elencando entre um dos fins que devem ser perquiridos o de "g) empregar pessoas com deficiência no setor público."

O problema da exclusão dessa minoria, como se vê, não tem causas de ordem exclusivamente legislativa. As Organizações Internacionais são pródigas em oficializar meios de proteção às pessoas com deficiência, especialmente quanto à sua inserção no mercado de trabalho. Falta ainda, na verdade, uma mais assídua realização de políticas públicas que deem

\footnotetext{
17 BRASIL. Presidência da República. Decreto n. 129, de 22 de maio de 1991. Promulga a Convenção $n$ 159, da Organização Internacional do Trabalho - OIT, sobre Reabilitação Profissional e Emprego de Pessoas Deficientes. Disponível em: http://www.planalto.gov.br/ccivil_03/decreto/1990-1994/d0129.htm. Acesso em: 30 jan. 2018.

18 BRASIL. Presidência da República. Decreto n. 129, de 22 de maio de 1991. Promulga a Convenção $n$ 159, da Organização Internacional do Trabalho - OIT, sobre Reabilitação Profissional e Emprego de Pessoas Deficientes. Disponível em: http://www.planalto.gov.br/ccivil_03/decreto/1990-1994/d0129.htm. Acesso em: 30 jan. 2018.
} 
ISSN 1981-3694

(DOI): $10.5902 / 1981369432608$

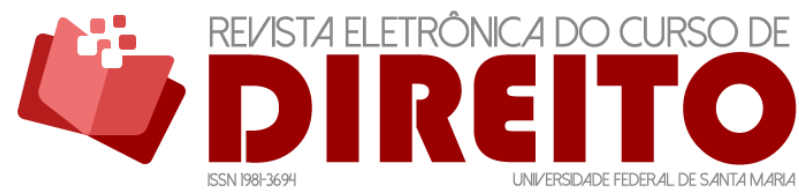

A RESERVA DE CARGOS E EMPREGOS PÚBLICOS PARA AS PESSOAS COM DEFICIÊNCIA COMO ESTRATÉGIA CONSTITUCIONAL RUMO À

IGUALDADE CONCRETA

EDILENE LÔBO BRUNO MARTINS TEIXEIRA

concretude aos citados princípios e regras, mediante o implemento de ações afirmativas, consoante ditame contido no artigo $27, \mathrm{I}, \mathrm{h})$, da CDPD.

A valorização e o incentivo à execução de programas de ação afirmativa no campo laboral têm singular importância na contemporaneidade. Isso é ainda mais verdade quando falamos daqueles que possuem alguma deficiência, os quais são muito mais vulneráveis aos prejuízos advindos das exigências produtivas modernas de alguns setores do mercado, muitos dos quais se colocam indiferentes às particularidades de cada trabalhador.

\subsection{Avanços na inclusão de pessoas com deficiência na iniciativa privada}

Nesse aspecto, podemos registrar alguns avanços na legislação e jurisprudência brasileiras. Quanto aos trabalhadores regidos pela Lei 8.213/1999, em sua grande maioria presentes no setor privado, já se estabeleceu que no caso de a organização contar com mais de cem empregados é obrigatória a contratação de dois a cinco por cento dos seus cargos com beneficiários reabilitados ou pessoas portadoras de deficiência, conforme o tamanho do quadro.

Dentre as várias mudanças sociais necessárias, também há que se estimular a alteração de consciência de acolhimento aos diferentes, investindo na educação formal e informal com a adoção de disciplinas propedêuticas obrigatórias que tratem da matéria, promovendo radical mudança de cultura. Como afirmam Goldschmidt e Palma, abordando especificamente a questão dos deficientes físicos, "o mercado de trabalho deve adaptar-se às necessidades do trabalhador deficiente físico, considerando-se o que já fora dito sobre a vida humana se sobrepor aos objetivos do mercado de capital e do lucro."19

Nessa empreitada, têm-se colhido alguns frutos, sobretudo em consequência de atuações pontuais do Ministério Público do Trabalho, como é o caso da seguinte decisão do TST, de novembro de 2017:

AGRAVO. AGRAVO DE INSTRUMENTO. RECURSO DE REVISTA INTERPOSTO NA VIGÊNCIA DA LEI No 13.015/14. ACÃO CIVIL PÚBLICA. CONTRATACÃO DE EMPREGADOS REABILITADOS OU PORTADORES DE DEFICIÊNCIA. DESCUMPRIMENTO DA COTA MÍNIMA PREVISTA EM LEI. A parte agravante não apresenta argumentos capazes de desconstituir a decisão que negou seguimento ao agravo de instrumento, uma vez que o recurso de revista não demonstrou pressuposto

\footnotetext{
${ }^{19}$ GOLDSCHMIDT, Rodrigo; PALMA, Darléa Carine. 0 direito fundamental do deficiente físico ao trabalho digno e sua inclusão no mercado de trabalho. Anais do Seminário Nacional de Dimensões Materiais e Eficaciais dos Direitos Fundamentais - DESCONTINUADO. 17 a 19/08/2011, Chapecó (SC), P. 251.Disponível em http://editora.unoesc.edu.br/index.php/seminarionacionaldedimensoes/article/view/911/0. Acesso em: 2 fev. 2018.
} 
ISSN 1981-3694

(DOI): $10.5902 / 1981369432608$

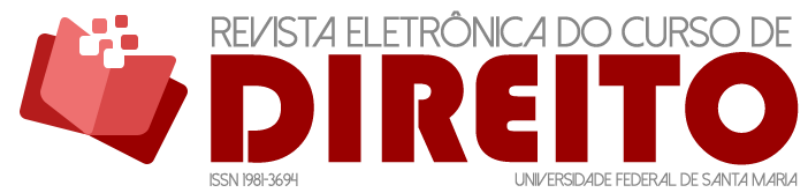

A RESERVA DE CARGOS E EMPREGOS PÚBLICOS PARA AS PESSOAS COM DEFICIÊNCIA COMO ESTRATÉGIA CONSTITUCIONAL RUMO À

IGUALDADE CONCRETA

EDILENE LÔBO

BRUNO MARTINS TEIXEIRA

intrínseco previsto no art. 896 da CLT. Na hipótese, a Corte Regional, valorando fatos e provas, concluiu que a ré não comprovou ter esgotado os meios de busca por trabalhadores reabilitados e portadores de deficiência. Anotou que a empresa empreendeu esforços insuficientes para o preenchimento da cota mínima prevista no art. 93 da Lei $n^{\circ} 8.213 / 91$, porquanto restritos à divulgação de vagas para funções de grande esforço físico. Afastou, assim, a alegação de que a contratação em número inferior à exigência legal se deveu à falta de candidatos habilitados, afigurando-se inviável cogitar de violação dos dispositivos de lei e da Constituição Federal indicados, ante o caráter fático da controvérsia. Agravo a que se nega provimento. ${ }^{20}$

Deve ser rompido o preconceito que ainda há em relação à contratação do trabalhador com deficiência, já que muitos deles são competentes e têm várias habilidades que quase sempre são ofuscadas pela percepção mais impactante que a deficiência, em si, pode causar.

Nessa luta não se pode perder de vista a imposição aos órgãos estatais e à iniciativa privada, em particular às instituições da seguridade social, para que atuem na adoção de políticas de readaptação e reinserção da pessoa com deficiência no mercado de trabalho. A um só tempo, tais medidas possibilitam a percepção e inclusão do outro em ambientes comuns, afastando o estigma e o ostracismo social dos diferentes.

\section{CONCRETIZAÇÃO CONSTITUCIONAL DO ACESSO A CARGO OU EMPREGO PÚBLICO.}

A Constituição da República, no art. 37, VIII, estabelece que "a lei reservará percentual dos cargos e empregos públicos para as pessoas portadoras de deficiência e definirá os critérios de sua admissão." ${ }^{21}$ Ponto que tem suscitado importantes debates diz respeito à forma pela qual essa reserva deve ser realizada, uma vez que lei ordinária há que estabelecer os limites procedimentais para a concretização da referida garantia sem ferir o preceito constitucional.

Ao se proceder primeiramente a uma interpretação literal da redação do artigo 37, inciso VIII, verifica-se que a intenção foi garantir a reserva de vagas dentro do quadro de pessoal da entidade ou esfera em questão. 0 que se depreende claramente da redação é que deve ser

20 BRASIL. Brasília. Tribunal Superior do Trabalho. Agravo de Instrumento $\mathrm{n}^{\circ}$ AIRR-18155.2013.5.09.0006, da $1^{\text {a }}$ Turma do TST. Relator: Walmir Oliveira da Costa. Brasília, DF. Publicação em $01 / 12 / 2018$ e transitado em julgado em 02/03/2018. Disponível em: http: / /aplicacao4.tst.jus.br/consultaProcessual/consultaTstNumUnica.do?conscsjt=\&numeroTst=181\&digit

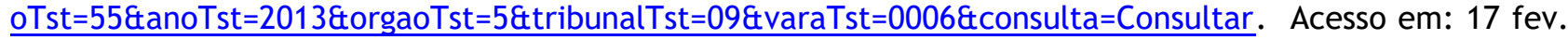
2018.

${ }^{21}$ BRASIL. Brasília. Presidência da República. Constituição da República Federativa do Brasil, de 05 de outubro de $1988 . \quad$ Disponível em: http://www.planalto.gov.br/ccivil_03/constituicao/constituicaocompilado.htm. Acesso em: 22 mar. 2018. 
ISSN 1981-3694

(DOI): $10.5902 / 1981369432608$

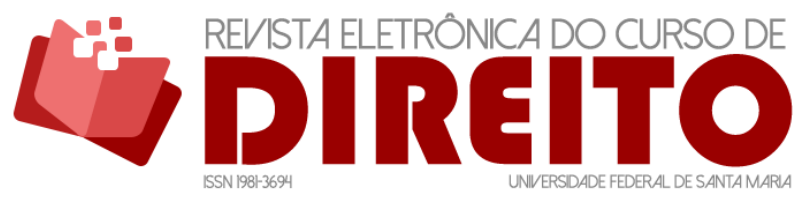

A RESERVA DE CARGOS E EMPREGOS PÚBLICOS PARA AS PESSOAS COM DEFICIÊNCIA COMO ESTRATÉGIA CONSTITUCIONAL RUMO À

IGUALDADE CONCRETA

EDILENE LÔBO BRUNO MARTINS TEIXEIRA

considerada a totalidade do quadro funcional, e não apenas a oferta nas vagas disponíveis nos concursos. Do contrário, a redação teria dito algo como "a lei reservará percentual das vagas ofertadas nos concursos públicos para serem disputadas exclusivamente por pessoas com deficiência”.

\subsection{A inclusão de pessoas com deficiência na esfera pública}

Não obstante, no âmbito federal, o legislador infraconstitucional tratou a questão de modo diverso da regra constitucional, gerando perplexidade.

0 artigo $5^{\circ}$, § $2^{\circ}$ da Lei $8.112 / 1990$ determina que às pessoas com deficiência é garantido "o direito de se inscrever em concurso público para provimento de cargo cujas atribuições sejam compatíveis com a deficiência de que são portadoras; para tais pessoas serão reservadas até $20 \%$ (vinte por cento) das vagas oferecidas no concurso."22 Já o Decreto 3.298/1999, estabelece o patamar mínimo de reserva de cinco por cento das vagas ofertadas no certame (artigo 37, § $1^{\circ}$ ), também fazendo referência à reserva de vagas em oferta nos concursos e não no quadro das entidades.

É importante ressaltar que as disposições das Leis 8.112/1990 e do Decreto 3.298/1999 são voltadas aos servidores públicos da União. No que toca aos Estados, municípios e ao Distrito Federal, o respectivo ordenamento poderá tratar de forma diversa, já que essas entidades podem legislar concorrentemente sobre a matéria, por força do artigo 24, XIV da Constituição de 1988. Apesar dessa independência legislativa, a maioria dos entes estatais vem seguindo o mesmo caminho inaugurado pela legislação federal, ou seja, fixam o percentual de reserva sobre a oferta de vagas via concursos e não dentro do quadro funcional respectivo.

Relativamente à categoria dos empregados públicos, conforme artigo 93 da Lei $8.213 / 1999$, a regra é de que a reserva se dará dentro do quadro da empresa e será proporcional ao número de empregados, devendo ser resguardados de dois a cinco por cento da totalidade dos cargos para beneficiários reabilitados ou pessoas com deficiência.

Para o caso dos cargos públicos, o legislador ordinário deveria ter mantido coerência com a regra constitucional e lançado mão de sistemática semelhante à do art. 93 da Lei $8.213 / 1999$, determinando o preenchimento de um percentual mínimo dos cargos e empregos

22 BRASIL. Brasília. Presidência da República. Lei n. ${ }^{\circ} 8.112$ de 11 de dezembro de 1990 - Disponível em: http://www.planalto.gov.br/ccivil_03/Leis/L8112cons.htm. Acesso em: 22 mar. 2018. 
ISSN 1981-3694

(DOI): $10.5902 / 1981369432608$

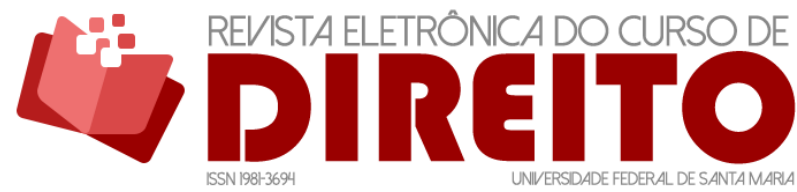

A RESERVA DE CARGOS E EMPREGOS PÚBLICOS PARA AS PESSOAS COM DEFICIÊNCIA COMO ESTRATÉGIA CONSTITUCIONAL RUMO À IGUALDADE CONCRETA

EDILENE LÔBO BRUNO MARTINS TEIXEIRA

públicos e não somente das vagas oportunizadas em concurso. Nesse sentido, é adequada a lição de Luis Roberto Barroso ao lembrar que:

[...] a Constituição figura hoje no centro do sistema jurídico, de onde irradia sua força normativa, dotada de supremacia formal e material. Funciona, assim, não apenas como parâmetro de validade para a ordem infraconstitucional, mas também como vetor de interpretação de todas as normas do sistema. ${ }^{23}$

Ademais, é preocupante o fato de que as entidades públicas, por questões diversas, têm organizado concursos com oferta cada vez menor de vagas, muitas das vezes com exclusiva previsão de cadastro de reserva, situação que tem garantido aos candidatos com deficiência tão somente a mera expectativa de nomeação.

É que, como o percentual máximo a ser reservado às pessoas com deficiência é de até 20 \% das vagas do concurso, só haverá chance desse candidato ser nomeado caso a administração pública convoque no mínimo cinco candidatos, por força do artigo $37, \S 2^{\circ}$ do Decreto $3.298 / 1999 .{ }^{24}$

Isso faz com que nos deparemos hoje com uma realidade em que pouquíssimas vagas são ocupadas por essas pessoas. Conforme avalia José dos Santos Carvalho Filho:

[...] não se tem visto, pelo menos até agora, maior preocupação dos órgãos estatais (salvo honrosas exceções) no que se refere ao recrutamento de pessoas portadoras de deficiência. Essa postura omissiva é inconstitucional: ao Poder Público cabe regular e incentivar essa participação, e isso porque, como sabido, trata-se de inegável instrumento de inclusão social. ${ }^{25}$

A ação afirmativa proposta pelo legislador constituinte objetiva a promoção de uma inclusão efetiva, isenta de subterfúgios que possam impedir a real concretização do princípio da não-discriminação, contido no artigo $3^{\circ} \mathrm{IV}$.

Como denuncia doutrina abalizada na abordagem do tema:

[...] a ação afirmativa estabelecida pela Constituição não foi integralmente implementada pela lei. A Constituição determina que será reservado percentual dos cargos e empregos públicos às pessoas com deficiência, ao passo que a lei (e

\footnotetext{
${ }^{23}$ BARROSO, Luís Roberto. Curso de Direito Constitucional Contemporâneo - Os conceitos fundamentais e a construção do novo modelo. São Paulo: Saraiva, 2009, p. 363.

24 Diz a redação do referido artigo: "Caso a aplicação do percentual de que trata o parágrafo anterior resulte em número fracionado, este deverá ser elevado até o primeiro número inteiro subsequente." (BRASIL, 1999) A remissão aqui é feita ao percentual mínimo fixado em $5 \%$. Levando-se em conta que a Lei $8112 / 90$ estabeleceu o máximo de $20 \%$, tem-se que é exigido no mínimo 5 nomeações para que se convoque candidatos com deficiência.

${ }^{25}$ CARVALHO FILHO, José dos Santos. Manual de Direito Administrativo. 23. ed., Rio de Janeiro - RJ: Lúmen Júris, 2010, p. 705.
} 
ISSN 1981-3694

(DOI): $10.5902 / 1981369432608$

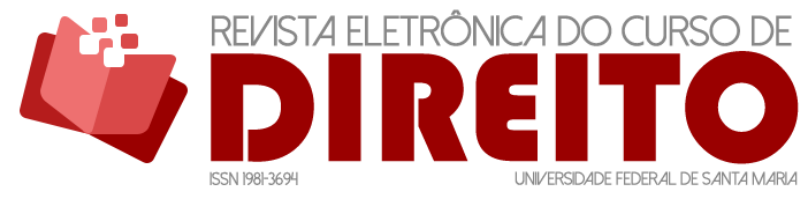

A RESERVA DE CARGOS E EMPREGOS PÚBLICOS PARA AS PESSOAS COM DEFICIÊNCIA COMO ESTRATÉGIA CONSTITUCIONAL RUMO À

IGUALDADE CONCRETA

EDILENE LÔBO BRUNO MARTINS TEIXEIRA

o decreto que a regulamenta) reserva apenas um percentual das vagas em disputa em cada concurso público. ${ }^{26}$

Em cuidadoso trabalho, os professores Dimitri Dimoulis e Leonardo Martins lançam mais luz à questão ao advertir que a supremacia constitucional deve ser sempre respeitada em sua finalidade de “estabelecer múltiplos e estritos limites ao legislador ordinário, 'desconfiando' de seu poder que pode oprimir os indivíduos e os grupos minoritários."27

O STF já se manifestou em defesa da tese da reserva real de vagas. O Ministro Cesar Peluso, no Mandado de Segurança n. 25.074, reconhecendo a contundência jurídica e clareza do preceito contido na redação do dispositivo em tela, pronunciou-se do seguinte modo:

[...] os portadores de deficiência tem direito de ocupar determinado número de cargos e empregos públicos, considerados em cada quadro funcional, segundo a percentagem que lhes reserve a lei, o que só pode apurar-se no confronto do total dos cargos e dos empregos, e não, é óbvio, perante o número aleatório de vagas que se ponham em cada concurso. ${ }^{28}$

Vê-se que, conquanto a lei ainda não trate literalmente da reserva real no caso da Administração Pública, doutrina e jurisprudência têm destacado que esse é o norte apontado claramente pela Carta de 1988.

\subsection{As normativas do CNJ e do CNMP para inclusão da pessoa com deficiência}

O Conselho Nacional de Justiça, em 22 de junho de 2016, editou a Resolução $n^{\circ}$ 230, que orienta a adequação das atividades dos órgãos do Poder Judiciário e de seus serviços auxiliares às determinações da Convenção Internacional sobre os Direitos da Pessoa com Deficiência, CDPD, e da Lei $n^{\circ} 13.146 / 2015$.

26 ARAÚJO, Luiz Alberto David e MAIA, Maurício. Inclusão e concurso público: análise crítica da jurisprudência sobre pessoas com deficiência. A \& C Revista de Direito Administrativo \& Constitucional, ano 16 - n. 65. Belo horizonte - MG: Fórum, 2016, p. 140. Disponível em

http: www.revistaaec.com/index.php/revistaaec/article/view/269. Acesso em: 1 nov. 2017.

27 DIMOULIS, Dimitri e MARTINS, Leonardo. Teoria Geral dos Direitos Fundamentais. 2. ed. São Paulo-SP: Revista dos Tribunais, 2009, p. 17.

28 BRASIL. Brasília. Supremo Tribunal Federal. Mandado de Segurança $\mathrm{n}^{\circ}$ 25.074. Relator Ministro Cezar Peluso. Originário do Distrito Federal. Decisão monocrática de 18 de outubro de 2004. Publicada no Diário Oficial da União. Brasília, 22 de outubro de 2004, p. 42. Disponível em: http://stf.jus.br/portal/jurisprudencia/listarJurisprudencia.asp?s1=\%28MS\%24\%2ESCLA\%2E+E+25074\%2ENU ME\%2E\%29+NAO+S\%2EPRES\%2E\&base=baseMonocraticas\&url=http://tinyurl.com/bp8pqjp. Acesso em: 2 fev. 2018 
ISSN 1981-3694

(DOI): $10.5902 / 1981369432608$

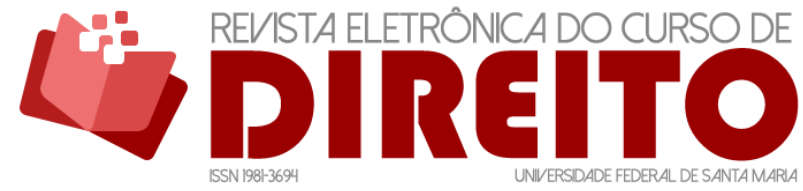

A RESERVA DE CARGOS E EMPREGOS PÚBLICOS PARA AS PESSOAS COM DEFICIÊNCIA COMO ESTRATÉGIA CONSTITUCIONAL RUMO À IGUALDADE CONCRETA

EDILENE LÔBO BRUNO MARTINS TEIXEIRA

No caput do artigo 10, essa Resolução previu a criação de comissões permanentes de acessibilidade e inclusão, para que fiscalizem, planejem, elaborem e acompanhem a aludida política. 0 inciso $X$ desse mesmo artigo, copiando a redação do artigo 37 , VIII, da Constituição, prevê “inclusão, em todos os editais de concursos públicos, da previsão constitucional de reserva de cargos para pessoas com deficiência, inclusive nos que tratam do ingresso na magistratura (CF, art.37, VIII)"29.

Na mesma linha seguiu o Conselho Nacional do Ministério Público, que explicitou claro posicionamento a respeito, orientando sobre como deve ser a operacionalização do cumprimento da comentada regra constitucional no âmbito público:

Se o quadro de carreira for estruturado em cargos e especialidades, a distribuição das vagas reservadas será feita proporcionalmente ao número de cargos em cada especialidade, de forma que para todos os cargos ou empregos públicos haja previsão explícita de reserva de vagas para pessoa com deficiência. Se, por outro lado, a Administração Pública disponibilizar uma só vaga, deve antes aferir se já detém em seus quadros um número significativo de servidores com deficiência no cargo a ser provido, de forma que a reserva comandada constitucionalmente esteja sendo cumprida, ou venha a ser paulatinamente cumprida.

[...]

Não tendo servidores ou empregados públicos com deficiência em parâmetros representativos razoáveis (lembre-se que ainda não dispomos de lei com reserva real de cargos e empregos públicos em cada órgão), poderá destinar esta única vaga para a reserva à pessoa com deficiência. Nesse caso, o edital do concurso público deverá ser claro no sentido de que a única vaga disponibilizada se destina ao provimento de cargo da reserva de vaga da pessoa com deficiência. ${ }^{30}$

Certamente que a adoção dessas normativas revela a extrema necessidade de que esses órgãos deem exemplos de inclusão de pessoas com deficiência nos seus quadros, em especial da carreira principal, eis que são de extrema visibilidade, como já dito.

A despeito disso, no Estado de São Paulo, no $185^{\circ}$ Concurso de ingresso na carreira de juiz, no ano de 2014 (em que já vigente a CDPD), foram disponibilizadas 215 vagas, sendo 204 de ampla concorrência e 11 (5\%) para pessoas com deficiência. ${ }^{31} 0$ resultado final revelou a

29 BRASIL. Conselho Nacional de Justiça. Resolução $n^{\circ}$ 230, de 22/06/2016. Brasília, DF. Disponível em: http:// www.cnj.jus.br/busca-atos-adm?documento=3141 Acesso em: 2 maio. 2018.

30 GUGEL, Maria Aparecida. Pessoa com Deficiência e o Direito ao Trabalho: reserva de cargos em empresas, emprego apoiado. Florianópolis: Obra Jurídica, 2007. p. 70-72 apud Conselho Nacional do Ministério Público. Guia de atuação do Ministério Público - Pessoa com deficiência, p. 32. Disponível em http://www.cnmp.mp.br/portal/publicacoes/245-cartilhas-e-manuais/9767-guia-de-atuacao-doministerio-publico-pessoa-com-deficiencia. Acesso em: 2 maio. 2018

31 Tribunal de Justiça do Estado de São Paulo. Edital do $185^{\circ}$ Concurso de provas e títulos para ingresso na magistratura do Estado de São Paulo. São Paulo, SP, 11 de junho de 2014, p. 01-03. Disponível em: https://www.vunesp.com.br/TJSP1401. Acesso em: 1 maio. 2018. 
ISSN 1981-3694

(DOI): $10.5902 / 1981369432608$

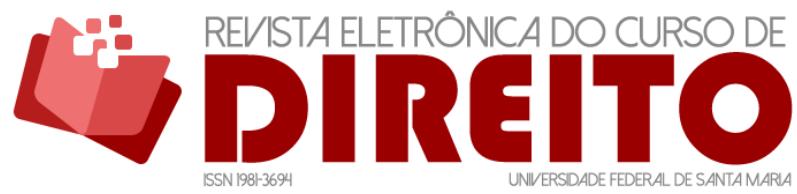

A RESERVA DE CARGOS E EMPREGOS PÚBLICOS PARA AS PESSOAS COM DEFICIÊNCIA COMO ESTRATÉGIA CONSTITUCIONAL RUMO À IGUALDADE CONCRETA

EDILENE LÔBO BRUNO MARTINS TEIXEIRA

aprovação de 80 concorrentes na disputa geral e apenas 01 com deficiência. ${ }^{32}$ Quadro ainda mais restrito se verificou no $186^{\circ}$ Concurso, no ano de 2015 , em que foram disponibilizadas 217 vagas, sendo 206 de ampla concorrência e 11(5\%) para pessoas com deficiência. ${ }^{33} \mathrm{O}$ resultado final revelou a aprovação de 77 concorrentes na disputa geral e nenhum com deficiência, pelo que se observa do relatório final. ${ }^{34}$ Logicamente, não se verá juízes ou juízas com deficiência, na prática.

No $87^{\circ}$ concurso realizado pelo Ministério Público do mesmo Estado, em 2010, foram 75 vagas para promotor de justiça, sendo 71 de ampla concorrência e 04 para pessoas com deficiência. ${ }^{35} \mathrm{O}$ resultado final indicou a aprovação de 73 candidatos na disputa geral e nenhum com deficiência ${ }^{36}$. Antes, no $86^{\circ}$ concurso do Ministério Público, de 2008 (em que não vigia a CDPD, mas o texto constitucional não deixava margens ao dever de inclusão), o resultado final não relaciona qualquer pessoa com deficiência. ${ }^{37}$ Das 79 vagas, 71 foram para ampla concorrência e 04 para pessoas com deficiência, vindo à aprovação apenas 52 concorrentes na disputa geral. ${ }^{38}$

Em Minas Gerais, segundo maior estado do país, não tem sido diferente. No último concurso encerrado para o cargo de juiz, em 2011, o Edital n. 01/2011 previu inicialmente a

32 Tribunal de Justiça do Estado de São Paulo. Lista de aprovados na prova oral do $185^{\circ}$ concurso de Provas e Títulos para Ingresso na Magistratura do Estado de São Paulo. São Paulo, SP, 08 de setembro de 2015. Disponível em: https: //www.vunesp.com.br/TJSP1401. Acesso em: 1 maio. 2018.

${ }^{33}$ Tribunal de Justiça do Estado de São Paulo. Edital do $186^{\circ}$ concurso de provas e títulos para ingresso na magistratura do Estado de São Paulo. São Paulo, SP, 10 de junho de 2015, p. 01-03. Disponível em: https://www.vunesp.com.br/TJSP1504. Acesso em: 1 maio. 2018.

34 Tribunal de Justiça do Estado de São Paulo. Lista de candidatos aprovados na avaliação de títulos no $186^{\circ}$ concurso de provas e títulos para ingresso na magistratura do Estado de São Paulo. São Paulo, SP, 16 de agosto de 2016. Disponível em: https://www.vunesp.com.br/TJSP1504. Acesso em: 1 maio. 2018.

35 Ministério Público do Estado de São Paulo. Edital do $87^{\circ}$ concurso de ingresso na carreira do Ministério Público - 2010. São Paulo, SP, 31 de dezembro de 2009, p. 01. Disponível em: http://www.mpsp.mp.br/portal/page/portal/concursos/membros/87_CONCURSO_INGRESSO. Acesso em: 1 maio. 2018.

36 Ministério Público do Estado de São Paulo. AVISO No 191/11 - PGJ. - Relatório final do $87^{\circ}$ concurso de ingresso na carreira do Ministério Público - 2010. São Paulo, SP, 14 de março de 2011. Disponível em: http://www.mpsp.mp.br/portal/page/portal/concursos/membros/87_CONCURSO_INGRESSO. Acesso em: 1 maio. 2018

37 Ministério Público do Estado de São Paulo. Edital do $86^{\circ}$ concurso de ingresso na carreira do Ministério Público - 2008. São Paulo, SP, 14 de agosto de 2008, p. 01. Disponível em: http://www.mpsp.mp.br/portal/page/portal/concursos/membros/87_CONCURSO_INGRESSO. Acesso em: 1 maio. 2018.

${ }^{38}$ Ministério Público do Estado de São Paulo. AVISO No 549/09 - PGJ. - Relatório final do $86^{\circ}$ concurso de ingresso na carreira do Ministério Público - 2008. São Paulo, SP, 31 de julho de 2009. Disponível em: http://www.mpsp.mp.br/portal/page/portal/home/interna/concursos/86_CONCURSO_INGRESSO_CARREIR A. Acesso em: 1 maio. 2018.

Revista Eletrônica do Curso de Direito da UFSM www.ufsm.br/revistadireito v. 14, n. 1 / 2019 e32608 
ISSN 1981-3694

(DOI): $10.5902 / 1981369432608$

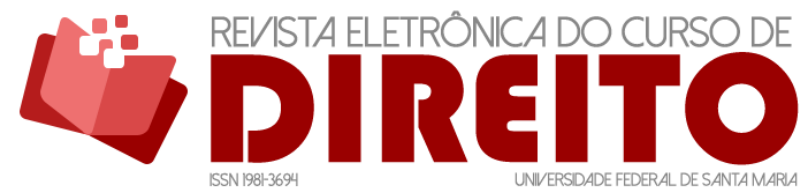

A RESERVA DE CARGOS E EMPREGOS PÚBLICOS PARA AS PESSOAS COM DEFICIÊNCIA COMO ESTRATÉGIA CONSTITUCIONAL RUMO À IGUALDADE CONCRETA

EDILENE LÔBO BRUNO MARTINS TEIXEIRA

oferta de 14 vagas, das quais 10\% deveriam ser destinadas a pessoas com deficiência ${ }^{39}$. Na etapa classificatória geral, 99 candidatos sem deficiência foram classificados, dentre os quais apenas 01 era cotista. ${ }^{40}$ Por sua vez, o Ministério Público mineiro, em seu LV concurso de 2017, destinou 36 vagas para ampla concorrência e 4 para pessoas com deficiência ${ }^{41}$. No resultado final, foram aprovados 31 candidatos da concorrência geral e nenhum com deficiência ${ }^{42}$.

\subsection{0 dever de fiscalização}

O legítimo consenso popular à execução de ações afirmativa visando à ampla promoção da participação efetiva de tais pessoas nos vários meandros da vida social, inclusive no tocante às oportunidades de trabalho, obriga a todos, representantes políticos, agentes e gestores públicos, organizações assistenciais, cidadãos, enfim, todos, a se engajarem assiduamente na luta pela implementação de políticas consentâneas com os referidos fundamentos.

Nesse norte, Luís Roberto Barroso é didático ao expor que:

A efetividade da Constituição há de assentar-se sobre alguns pressupostos indispensáveis. Como foi referido, é preciso que haja, da parte do constituinte, senso de realidade, para que não pretenda normatizar o inalcançável, o que seja materialmente impossível em dado momento e lugar. Ademais, deverá ele atuar com boa técnica legislativa, para que seja possível vislumbrar adequadamente as posições em que se investem os indivíduos, assim como os bens jurídicos protegidos e as condutas exigíveis. Em terceiro lugar, impõe-se ao Poder Público vontade política, a concreta determinação de tornar realidade os comandos constitucionais. E, por fim, é indispensável o consciente exercício de cidadania,

\footnotetext{
39 Tribunal de Justiça do Estado de Minas Gerais. Edital $n^{\circ}$ 01/2011, do concurso público de provas e títulos para ingresso na carreira da magistratura do Estado de Minas Gerais. Belo Horizonte, MG, 14 de outubro de 2011, p. 01 . Disponível em: http://www.tjmg.jus.br/portaltjmg/transparencia/concursos/concurso-juiz-de-direito-substituto-edital-n-01-2011-1.htm. Acesso em: 1 maio. 2018.

40 Tribunal de Justiça do Estado de Minas Gerais. Lista de classificação final do concurso público de provas e títulos para ingresso na carreira da magistratura do Estado de Minas Gerais - Edital $\mathrm{n}$. 01/2011. Belo Horizonte, MG, 26 de março de 2013. Disponível em: http://www.tjmg.jus.br/portaltjmg/transparencia/concursos/classificacao-final-dje-de-26-03-2013.htm. Acesso em: 1 maio. 2018.

41 Ministério Público do Estado de Minas Gerais. Edital do LV concurso para ingresso na carreira do Ministério Público do Estado de Minas Gerais. Belo Horizonte, MG, 17 de janeiro de 2017, p. 01. Disponível em: https://www.mpmg.mp.br/acesso-a-informacao/concursos/membros/lv-concurso-depromotor-de-justica-substituto/lv-concurso-de-promotor-de-justica-substituto.htm. Acesso em: 1 maio 2018.

${ }^{42}$ Ministério Público do Estado de Minas Gerais. Resultado final do LV concurso para ingresso na carreira do Ministério Público do Estado de Minas Gerais. Belo Horizonte, MG, 30 de novembro de 2017. Disponível em: https://www.mpmg.mp.br/acesso-a-informacao/concursos/membros/lv-concurso-depromotor-de-justica-substituto/lv-concurso-de-promotor-de-justica-substituto.htm. Acesso em: 1 maio 2018.
} 
mediante a exigência, por via de articulação política e de medidas judiciais, da realização dos valores objetivos e dos direitos subjetivos constitucionais. ${ }^{43}$

Aliás, no aspecto técnico-jurídico deve-se atentar para o fato de que:

O administrador pode e deve atuar tendo por fundamento direto a Constituição e independentemente, em muitos casos, de qualquer manifestação do legislador ordinário. 0 princípio da legalidade transmuda-se, assim, em princípio da constitucionalidade ou, talvez mais propriamente, em princípio da juridicidade, compreendendo sua subordinação à Constituição e à lei, nessa ordem. ${ }^{44}$

Dessa forma, é preciso ter claro que, tanto pela ótica jurídico-constitucional quanto pelo viés principiológico, não há empecilhos de ordem prática que justifiquem a mantença do aludido estado de exclusão, especialmente nos setores públicos. ${ }^{45}$

Tal situação demanda que nos mantenhamos empenhados em fazer valer a vontade política e o exercício de cidadania de todos. Para tanto, há que lançarmos mão dos diversos meios legítimos disponíveis, sempre se pautando, precipuamente, nos princípios da igualdade e da dignidade da pessoa humana.

Particularmente nessa quadra avulta o dever de fiscalização dos órgãos responsáveis, que não podem ser lenientes ou alheios à necessidade de implementação da política inclusiva debatida, como apta a iniciar o saldo da promessa constitucional não cumprida de erradicação da marginalização das pessoas com deficiência.

\footnotetext{
${ }^{43}$ BARROSO, Luís Roberto. Curso de Direito Constitucional Contemporâneo - Os conceitos fundamentais e a construção do novo modelo. São Paulo: Saraiva, 2009, p. 221.

${ }^{44}$ BARROSO, Luís Roberto. Curso de Direito Constitucional Contemporâneo - Os conceitos fundamentais e a construção do novo modelo. São Paulo: Saraiva, 2009, p. 375-376.

45 Nesse ponto, é útil comentar como vem sendo tratada a questão relativa à obrigatoriedade da reserva de vagas para estagiários no âmbito público, dada a estreita relação entre educação e trabalho presente no vínculo de estágio. A Lei n. 11.788/2008 - Lei Nacional do Estágio - determina que dez por cento das vagas sejam reservadas para pessoas com deficiência. Tratando especificamente dos estágios na esfera do funcionalismo público federal, o Ministério do Planejamento, Desenvolvimento e Gestão editou a Orientação Normativa $N^{\circ} 2$, de $24 / 06 / 2016$, cujo texto reitera a obrigação de resguardar dez por cento das vagas para estagiários com deficiência dentro do órgão. Aspecto importante está no fato de que esta regra não trata da reserva em relação ao processo de admissão dos estagiários, mas manda que o administrador observe o total do quadro quando do preenchimento das vagas. Além disso, diversifica o mecanismo inclusivo ao estabelecer, no art. $7^{\circ}$, § $2^{\circ}$, uma subdivisão equânime desse percentual entre todos os níveis de escolaridade. Brasília. Presidência da República. Ministério do Planejamento, Orçamento e Gestão. Orientação Normativa n.02, de 24 de junho de 2016 - Estabelece orientações sobre a aceitação de estagiários no âmbito da Administração Pública federal direta, autárquica e fundacional. Publicada no DOU de 28/06/2016, seção I, pág. 44. Disponível em: http://www.imprensanacional.gov.br. Acesso em: 24 fev. 2018.
} 


\section{CONCLUSÃO}

O intento de incluir as pessoas com deficiência no mercado de trabalho, em geral, ainda não atingiu o nível de democratização condizente com a ordem constitucional vigente. Na esfera pública, esse panorama é ainda mais preocupante. Daí se pode ver que apesar da ampla proteção jurídica proporcionada pela legislação internacional e pela Constituição, ainda há fortes imperativos socioeconômicos que contrastam com esse objetivo.

Há que ser ressaltada a clara conexão entre o compromisso constitucional de promover ao nível de máxima concretude possível a igualdade de oportunidades entre pessoas sem e com deficiência, previsto no artigo 37, VIII, e os demais dispositivos que informam o escopo preambular de assegurar uma sociedade pluralista e sem preconceitos.

A regra contida no artigo 93 da Lei 8.213/1999, que previu a reserva de dois a cinco por cento das vagas de emprego para beneficiários reabilitados ou pessoas com deficiência, no campo privado, permite razoável comparação no sentido possibilitar semelhante solução na esfera pública, asserindo que nenhuma razão assiste à alegação de que haveria dificuldades operacionais para aplicar-se à admissão dos servidores públicos o quanto definido na redação do artigo 37, VIII da Constituição.

Apesar de o legislador ordinário ter sido dissonante, até o momento, com o teor do dispositivo constitucional, percebe-se que a jurisprudência e a doutrina têm abraçado cada vez mais a tese da máxima concretização do preceito constitucional analisado. Essa constatação indica a necessária interpretação do texto dessas leis conforme com a Constituição. E também permite ensaiar a responsabilidade penal dos entes omissos na adoção de políticas inclusivas das pessoas com deficiência, nela incluída os órgãos fiscais omissos ou lenientes.

Nessa direção, deve ser dado importante destaque à iniciativa do Conselho Nacional do Ministério Público ao recomendar que se realizem concursos específicos com ofertas de vagas exclusivamente para pessoas com deficiência, sempre que verificada a falta de quantidade razoável de servidores nessas condições, o que nos leva a exortar a essa Órgão, assim como ao Judiciário, que se volte para o seu interior e ali faça valer a mesma recomendação.

Sob outro ângulo, é preciso reconhecer que a ausência de lei ordinária regulamentando especificamente a efetivação da reserva real de vagas dentro dos quadros do funcionalismo público é vista como um empecilho para que se concretize definitivamente o objetivo em tela, já que a previsão legislativa ainda é importante fonte de legitimação do direito, sobretudo no 
ISSN 1981-3694

(DOI): $10.5902 / 1981369432608$

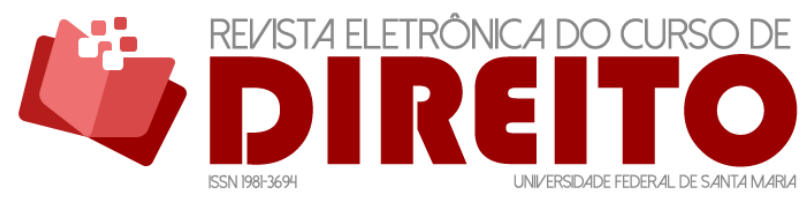

A RESERVA DE CARGOS E EMPREGOS PÚBLICOS PARA AS PESSOAS COM DEFICIÊNCIA COMO ESTRATÉGIA CONSTITUCIONAL RUMO À

funcionalismo público, o que poderia se resolver com a ativação da função legislativa, a ser provocada até mesmo por meio de projeto de lei de iniciativa popular. O problema reclama, é fato, produção legislativa mais coerente com os anseios populares materializados na Constituição, mais segura do ponto de vista jurídico, além de mais amadurecida no que diz respeito à correta compreensão dos benefícios da inclusão para a coletividade em geral.

Por fim, dada a necessidade de continuar oferecendo serviços públicos de qualidade, deve-se realçar a exigência de maiores investimentos na manutenção do contínuo engajamento das diversas entidades comprometidas com a inclusão das pessoas com deficiência, máxime apoiando o implemento de ações voltadas à capacitação e à valorização das habilidades dessas pessoas. Nesse causal, não se pode descurar do dever imposto aos órgãos públicos encarregados da seguridade social, para que adotem mesmas práticas, sob risco de responsabilidade pessoal de seus dirigentes.

\section{REFERÊNCIAS}

ARAÚJO, Luiz Alberto David e MAIA, Maurício. Inclusão e concurso público: análise crítica da jurisprudência sobre pessoas com deficiência. A \& C Revista de Direito Administrativo \& Constitucional, ano $16-\mathrm{n}$. 65. Belo horizonte - MG: Fórum, 2016. Disponível em: http:www.revistaaec.com/index.php/revistaaec/article/view/269. Acesso em: 1 nov. 2017.

BARBOSA, Rui. Oração aos Moços. 5. Ed. Rio de Janeiro: Edições Casa de Rui Barbosa, 1999.

BARROSO, Luís Roberto. A judicialização da vida e o papel do Supremo Tribunal Federal. Belo Horizonte: Forum, 2018.

BARROSO, Luís Roberto. Curso de Direito Constitucional Contemporâneo - Os conceitos fundamentais e a construção do novo modelo. São Paulo: Saraiva, 2009.

BRASIL. Brasília. Presidência da República. Constituição da República Federativa do Brasil, de 05 de outubro de 1988. Disponível em:

http://www.planalto.gov.br/ccivil_03/constituicao/constituicaocompilado.htm. Acesso em: 22 mar. 2018.

BRASIL. Brasília. Presidência da República. Lei nº 8.112 de 11 de dezembro de 1990.

Disponível em: http://www.planalto.gov.br/ccivil_03/Leis/L8112cons.htm. Acesso em: 22 mar. 2018.

BRASIL. Brasília. Presidência da República. Lei n 8.213, de 24 de julho de 1991. Disponível em: http://www.planalto.gov.br/Ccivil_03/leis/L8213cons.htm. Acesso em: 22 mar. 2018. 
ISSN 1981-3694

(DOI): $10.5902 / 1981369432608$

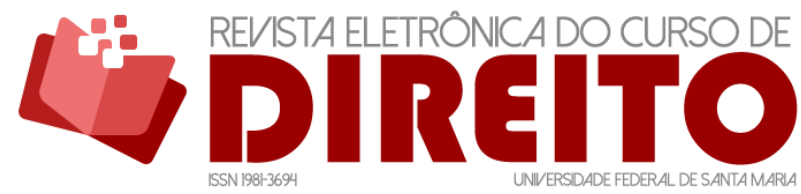

A RESERVA DE CARGOS E EMPREGOS PÚBLICOS PARA AS PESSOAS COM DEFICIÊNCIA COMO ESTRATÉGIA CONSTITUCIONAL RUMO À IGUALDADE CONCRETA

EDILENE LÔBO BRUNO MARTINS TEIXEIRA

BRASIL. Brasília. Presidência da República. Lei $n^{\circ}$ 13.146, de 06/07/2015. Disponível em:

http://www.planalto.gov.br/ccivil_03/_ato2015-2018/2015/lei//13146.htm. Acesso em: 22 mar. 2018.

BRASIL. Brasília. Presidência da República. Decreto 6.949, de 25/08/2009. Disponível em: http://www.planalto.gov.br/ccivil_03/_ato2007-2010/2009/decreto/d6949.htm. Acesso em: 5 set. 2017.

BRASIL. Brasília. Presidência da República. Decreto $n^{\circ}$ 129, de 22 de maio de 1991. Promulga a Convenção n 159, da Organização Internacional do Trabalho-OIT, sobre Reabilitação Profissional e Emprego de Pessoas Deficientes. Disponível em: www.planalto.gov.br/ccivil_03/decreto/19901994/d0129.htm. Acesso em: 30 jan. 2018.

BRASIL. Brasília. Ministério do Planejamento, Orçamento e Gestão. Orientação Normativa n.02, de 24 de junho de 2016 - Estabelece orientações sobre a aceitação de estagiários no âmbito da Administração Pública federal direta, autárquica e fundacional. Disponível em http: / /www.imprensanacional.gov.br Publicada no DOU de 28/06/2016, seção I, pág. 44. Acesso em: 24 fev. 2018.

BRASIL. Brasília. Supremo Tribunal Federal. Mandado de Segurança $n^{\circ}$ 25.074. Relator Ministro Cezar Peluso. Originário do Distrito Federal. Decisão monocrática de 18 de outubro de 2004. Publicada no Diário Oficial da União. Brasília, 22 de outubro de 2004, p. 42. Disponível em: http://stf.jus.br/portal/jurisprudencia/listarJurisprudencia.asp?s1=\%28MS\%24\%2ESCLA\%2E+E+25 074\%2ENUME\%2E\%29+NAO+S\%2EPRES\%2E\&base=baseMonocraticas\&url=http: / / tinyurl.com/bp8pqi p. Acesso em: 02 fev. 2018.

BRASIL. Brasília. Tribunal Superior do Trabalho. Agravo de Instrumento $n^{\circ}$ AIRR-18155.2013.5.09.0006, da $1^{\text {a }}$ Turma do TST. Relator: Walmir Oliveira da Costa. Brasília, DF. Publicação em 01/12/2018 e transitado em julgado em 02/03/2018. Disponível em: http: / /aplicacao4.tst.jus.br/consultaProcessual/consultaTstNumUnica.do?conscsjt=\&numeroTst= $181 \&$ digitoTst $=55 \&$ anoTst $=2013 \&$ torgaoTst $=5 \&$ tribunalTst=09\&varaTst=0006\& consulta $=$ Consultar . Acesso em: 17 fev. 2018.

BRASIL. Brasília. Conselho Nacional de Justiça. Resolução $n^{\circ} 230$, de 22/06/2016. Brasília, DF. Disponível em: http://www.cnj.jus.br/busca-atos-adm?documento=3141. Acesso em: 2 maio. 2018.

BRASIL. Brasília. Supremo Tribunal Federal. Ação Direta de Inconstitucionalidade $\mathrm{n}^{\circ}$ 2.649. Relatora: Carmem Lúcia. DF. Publicação DJE em 17/10/2008. Disponível em: http://www.stf.jus.br/portal/constituicao/artigobd.asp?item=\%202. Acesso em: 24 fev. 2018.

CARVALHO FILHO, José dos Santos. Manual de Direito Administrativo. 23. ed., Rio de Janeiro RJ: Lúmen Júris, 2010.

CONSELHO NACIONAL DO MINISTÉRIO PÚBLICO. Guia de atuação do Ministério Público - Pessoa com deficiência. Disponível em: http://www.cnmp.mp.br/portal/publicacoes/245-cartilhas-emanuais/9767-guia-de-atuacao-do-ministerio-publico-pessoa-com-deficiencia Acesso em: 2 mai. 2018. 
ISSN 1981-3694

(DOI): $10.5902 / 1981369432608$

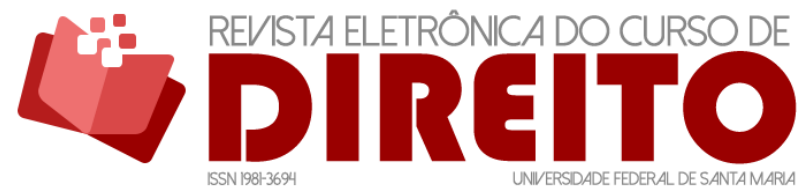

A RESERVA DE CARGOS E EMPREGOS PÚBLICOS PARA AS PESSOAS COM DEFICIÊNCIA COMO ESTRATÉGIA CONSTITUCIONAL RUMO À IGUALDADE CONCRETA

DIMOULIS, Dimitri; MARTINS, Leonardo. Teoria Geral dos Direitos Fundamentais. 2. ed. São Paulo-SP: Revista dos Tribunais, 2009.

GOLDSCHMIDT, Rodrigo; PALMA, Darléa Carine. 0 direito fundamental do deficiente físico ao trabalho digno e sua inclusão no mercado de trabalho. Anais do Seminário Nacional de Dimensões Materiais e Eficaciais dos Direitos Fundamentais - DESCONTINUADO. 17 a 19/08/2011, Chapecó (SC) .Disponível em

http://editora.unoesc.edu.br/index.php/seminarionacionaldedimensoes/article/view/911/0. Acesso em: 2 fev.2018.

GUGEL, Maria Aparecida. Pessoas com deficiência e o direito ao concurso público. - Reserva de cargos e empregos públicos - Administração Pública direta e indireta. 3. ed. Goiânia: Editora da UGC, 2016. Disponível em:

http: www.revistaaec.com/index.php/revistaaec/article/view/269. Acesso em: 1 nov. 2017.

INSTITUTO BRASILEIRO DE GEOGRAFIA E ESTATÍ́STICA - IBGE. Rio de Janeiro: RJ. Boletim estatístico - censo 2010. Disponível em:

https://biblioteca.ibge.gov.br/visualizacao/periodicos/94/cd_2010_religiao_deficiencia.pdf. Acesso em: 24 mar. 2018.

MARTINS, Sérgio Pinto. Direito do Trabalho. 19. ed. São Paulo: Atlas, 2001.

MINISTÉRIO DO TRABALHO E EMPREGO. Relatório Anual de Informações Sociais - RAIS - 2016. In: Dados Nacionais 2016, 3. Análise dos principais resultados. Brasília - DF. Disponível em: http://pdet.mte.gov.br/rais?view=default. Acesso em: 1 maio. 2018.

MINISTÉRIO PÚBLICO DO ESTADO DE MINAS GERAIS. Edital do LV concurso para ingresso na carreira do Ministério Público do Estado de Minas Gerais. Belo Horizonte, MG, 17 de janeiro de 2017, p. 01. Disponível em: https://www.mpmg.mp.br/acesso-a-

informacao/concursos/membros/lv-concurso-de-promotor-de-justica-substituto/lv-concurso-depromotor-de-justica-substituto.htm. Acesso em: 1 maio. 2018.

MINISTÉRIO PÚBLICO DO ESTADO DE MINAS GERAIS. Resultado final do LV concurso para ingresso na carreira do Ministério Público do Estado de Minas Gerais. Belo Horizonte, MG, 30 de novembro de 2017. Disponível em: https: / / www.mpmg.mp.br/acesso-ainformacao/concursos/membros/lv-concurso-de-promotor-de-justica-substituto/lv-concurso-depromotor-de-justica-substituto.htm. Acesso em: 1 maio. 2018.

MINISTÉRIO PÚBLICO DO ESTADO DE SÃO PAULO. AVISO No 191/11 - PGJ. - Relatório final do $87^{\circ}$ concurso de ingresso na carreira do Ministério Público - 2010. São Paulo, SP, 14 de março de 2011. Disponível em:

http://www.mpsp.mp.br/portal/page/portal/concursos/membros/87_CONCURSO_INGRESSO. Acesso em: 1 maio. 2018.

MINISTÉRIO PÚBLICO DO ESTADO DE SÃO PAULO. AVISO N 549/09 - PGJ. - Relatório final do $86^{\circ}$ concurso de ingresso na carreira do Ministério Público - 2008. São Paulo, SP, 31 de julho de 2009. Disponível em:

http://www.mpsp.mp.br/portal/page/portal/home/interna/concursos/86_CONCURSO_INGRESS O_CARREIRA. Acesso em: 01 maio 2018. 
ISSN 1981-3694

(DOI): $10.5902 / 1981369432608$

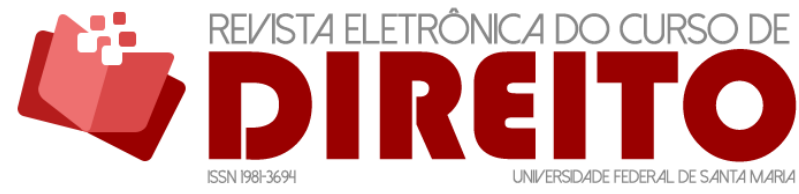

A RESERVA DE CARGOS E EMPREGOS PÚBLICOS PARA AS PESSOAS COM DEFICIÊNCIA COMO ESTRATÉGIA CONSTITUCIONAL RUMO À

IGUALDADE CONCRETA

MINISTÉRIO PÚBLICO DO ESTADO DE SÃO PAULO. Edital do $86^{\circ}$ concurso de ingresso na carreira do Ministério Público - 2008. São Paulo, SP, 14 de agosto de 2008. Disponível em: http://www.mpsp.mp.br/portal/page/portal/concursos/membros/87_CONCURSO_INGRESSO. Acesso em: 1 maio de 2018.

MINISTÉRIO PÚBLICO DO ESTADO DE SÃO PAULO. Edital do $87^{\circ}$ concurso de ingresso na carreira do Ministério Público - 2010. São Paulo, SP, 31 de dezembro de 2009, p. 01. Disponível em: http://www.mpsp.mp.br/portal/page/portal/concursos/membros/87_CONCURSO_INGRESSO Acesso em: 1 maio 2018.

MIRANDA, Jorge. Direitos Fundamentais. Coimbra: Edições Almedina S.A., 2017.

ORGANIZAÇÃO DAS NAÇÕES UNIDAS - ONU. Declaração Universal dos Direitos Humanos. Aprovada pela Resolução n.217, durante a assembleia-Geral da ONU, em Paris, França, em 10/12/1948. Disponível em: https://nacoesunidas.org/wp-content/uploads/2018/10/DUDH.pdf. Acesso em: 22 jan. 2018.

ROCHA, Carmen Lúcia Antunes. Ação Afirmativa: O Conteúdo Democrático do Princípio da Igualdade Jurídica. Revista da Informação Legislativa, v. 33, n 131, jul./set. de 1996. Disponível em: http://www2.senado.gov.br/bdsf/item/id/176462. Acesso em: 5 fev. 2017.

SILVA, José Afonso da. Curso de direito constitucional positivo. 40. ed. São Paulo: Malheiros, 2017.

TRIBUNAL DE JUSTIÇA DO ESTADO DE MINAS GERAIS. Edital n. 01/2011, do concurso público de provas e títulos para ingresso na carreira da magistratura do Estado de Minas Gerais. Belo Horizonte, MG, 14 de outubro de 2011, p. 01. Disponível em: http://www.tjmg.jus.br/portaltjmg/transparencia/concursos/concurso-juiz-de-direito-substituto-edital-n-01-2011-1.htm. Acesso em: 1 maio. 2018.

TRIBUNAL DE JUSTIÇA DO ESTADO DE MINAS GERAIS. Lista de classificação final do concurso público de provas e títulos para ingresso na carreira da magistratura do Estado de Minas Gerais - Edital n. 01/2011. Belo Horizonte, MG, 26 de março de 2013. Disponível em: http://www.tjmg.jus.br/portal-tjmg/transparencia/concursos/classificacao-final-dje-de-26-032013.htm. Acesso em: 1 maio. 2018.

TRIBUNAL DE JUSTIÇA DO ESTADO DE SÃO PAULO. Edital do $185^{\circ}$ Concurso de provas e títulos para ingresso na magistratura do Estado de São Paulo. São Paulo, SP, 11 de junho de 2014. Disponível em: https://www.vunesp.com.br/TJSP1401. Acesso em: 1 maio. 2018.

TRIBUNAL DE JUSTIÇA DO ESTADO DE SÃO PAULO. Edital do $186^{\circ}$ concurso de provas e títulos para ingresso na magistratura do Estado de São Paulo. São Paulo, SP, 10 de junho de 2015, p. 01-03. Disponível em: https://www.vunesp.com.br/TJSP1504. Acesso em: 1 maio. 2018.

TRIBUNAL DE JUSTIÇA DO ESTADO DE SÃO PAULO. Lista de aprovados na prova oral do $185^{\circ}$ concurso de Provas e Títulos para Ingresso na Magistratura do Estado de São Paulo. São Paulo, SP, 08 de setembro de 2015. Disponível em: https: //www.vunesp.com.br/TJSP1401 Acesso em: 01 maio. 2018. 
ISSN 1981-3694

(DOI): $10.5902 / 1981369432608$

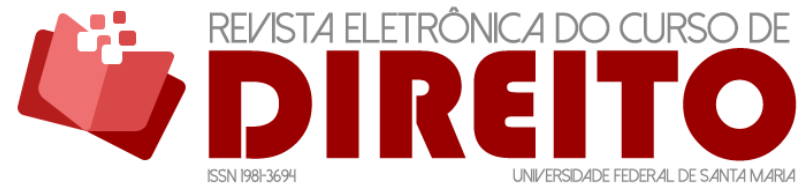

A RESERVA DE CARGOS E EMPREGOS PÚBLICOS PARA AS PESSOAS COM DEFICIÊNCIA COMO ESTRATÉGIA CONSTITUCIONAL RUMO À

TRIBUNAL DE JUSTIÇA DO ESTADO DE SÃO PAULO. Lista de candidatos aprovados na avaliação de títulos no $186^{\circ}$ concurso de provas e títulos para ingresso na magistratura do Estado de São Paulo. São Paulo, SP, 16 de agosto de 2016. Disponível em:

https://www.vunesp.com.br/TJSP1504. Acesso em: 01 maio. 2018.

Recebido em: 15.05.2018 / Aprovado em: 01.04.2019 / Publicado em: 06.05.2019

\section{COMO FAZER REFERÊNCIA AO ARTIGO (ABNT):}

LÔBO, Edilene; TEIXEIRA, Bruno Martins. A reserva de cargos e empregos públicos para as pessoas com deficiência como estratégia constitucional rumo à igualdade concreta. Revista Eletrônica do Curso de Direito da UFSM, Santa Maria, RS, v. 14, n. 1, e32608, jan./abr. 2019. ISSN 1981-3694. DOI:

http://dx.doi.org/10.5902/1981369432608. Disponível em:

https://periodicos.ufsm.br/revistadireito/article/view/32608 Acesso em: dia mês. ano.

Direitos autorais 2019 Revista Eletrônica do Curso de Direito da UFSM

Editores responsáveis: Rafael Santos de Oliveira e Angela Araujo da Silveira Espindola

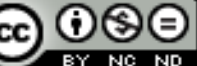

Este obra está licenciado com uma Licença Creative Commons Atribuição-NãoComercial-SemDerivações 4.0 Internacional.

\section{SOBRE OS AUTORES}

\section{EDILENE LÔBO}

Doutora pela Pontifícia Universidade Católica de Minas Gerais (2010). Mestre em Direito pela Universidade Federal de Minas Gerais (2005). Graduada em Direito pela Universidade de Itaúna (1995). Professora do Mestrado e da Graduação em Direito pela Universidade de Itaúna. Tem experiência na área do Direito Processual Civil, Penal e Eleitoral; Direito Administrativo, Eleitoral e Constitucional.

\section{BRUNO MARTINS TEIXEIRA}

Mestrando em Direito - Linha de pesquisa: Proteção dos Direitos Fundamentais, pela Universidade de Itaúna - UIT e possui especialização em Direito do Trabalho e Processo do Trabalho pela Universidade Gama Filho - RJ (2009). Servidor técnicoadministrativo do Centro Federal de Educação Tecnológica de Minas Gerais (CEFET-MG) - Campus Divinópolis e Advogado. 